\title{
Refleksi Dinamika Kebebasan Akademis dalam Pendidikan Islam
}

\author{
MUSADDAD HARAHAP \\ Fakultas Agama Islam (FAI) Universitas Islam Riau (UIR) Pekanbaru \\ Jl. Kaharuddin Nasution, No. 113, Perhentian Marpoyan Pekanbaru 28284 \\ e-mail: musaddad_hrp@yahoo.co.id
}

\begin{abstract}
Abstrak: kebebasan akademis didefinisikan sebagai tiadanya pengekangan, hukuman, dan intimidasi berkenaan dengan pengkajian, penelitian, pengujian lisan, dan pandangan terhadap pengetahuan. Istilah bebas itu merupakan aktivitas yang dilakukan secara sadar yang disertai dengan rasa tunduk dan patuh kepada ruhani dengan cara mematuhi undang-undang serta hukum akhlaqiah yang telah ditetapkan oleh agama. Sedangkan akademis diartikan dengan sesuatu yang berhubungan dengan ilmu pengetahuan, bersifat ilmiah dan juga pendidikan. Walaupun demikian, kebebasan dari sudut pandang ini berarti adanya posisi aman bagi setiap orang untuk melakukan aktivitas kehidupan tanpa dibebani oleh rasa khawatir oleh tekanan dari pihak-pihak tertentu. Pendefinisian kebebasan akdemis dapat dipahami bahwa para ilmuwan dengan segala keahliannya membutuhkan suasana yang kondusif tanpa ada intervensi dari pihak-pihak tertentu sehingga akan memungkinkan para ilmuwan dapat mencari, menggali, berinovasi dan mengembangkan ilmu pendidikan islam, karena pada hakikatnya ilmu itu tidak lepas dari sumber Ilmu itu sendiri yaitu Allah SWT. Dengan kebebasan akademis dalam arti positif telah terbukti mampu melahirkan para ulama atau ilmuwan muslim. Ini adalah bukti nyata bahwa ajaran Islam telah mampu mendongkrak dan memotivasi penganutnya untuk dapat semaksimal mungkin mendayagunakan potensi kemanusiannya secara mandiri dan aman dari tekanan.
\end{abstract}

Kata Kunci: Dinamika, Kebebasan Akademis, Pendidikan Islam

\section{PENDAHULUAN}

Dalam diskursus sejarah sosial pendidikan Islam, kebebasan akademis menjadi wacana yang sangat menarik bagi para sarjana dewasa ini, terutama kebebasan akademis di zaman Islam klasik. Lahirnya tokoh-tokoh pemikir muslim merupakan fakta sejarah atas kecintaan mereka terhadap ilmu pengetahuan. Berdasarkan kecintaan, minat dan perhatian mereka ini justru terakomodir oleh suasana kondusif yaitu adanya dukungan yang positif dari berbagai elemen baik sesama ilmuwan, masyarakat, pemerintah, terutama ajaran agama Islam itu sendiri. Namun pada waktu dan kondisi yang bersamaan tidak jarang para ilmuwan ini mendapat respon negatif oleh pihakpihak tertentu, baik dari masyarakat, pemerintah, maupun agamawannya. Jadi keadaan demikian sebenarnya menjadi dua hal yang saling bertolak belakang.

Adapun perjalanan sejarah pendidikan Islam dari sisi tertentu 
seperti kebebasan akademis ini pada gilirannya masih diselimuti oleh misteri, di satu sisi memang dengan adanya suasana egaliter dalam dunia pendidikan Islam terbukti mampu melahirkan ulama dan ilmuwan lintas disiplin dan mazhab, maka disisi yang lain misteri itu masih menyelimuti bagi mereka yang mendapat tekanan dan perlawanan. Sulit untuk memastikan kenapa mereka harus menjadi terisolir apakah memang mereka benar-benar salah atau bahkan ada motif lain dibalik peristiwa-peristiwa menyedihkan tersebut, dan hal itu seyogianya tidak lagi harus terjadi. Oleh karenanya dalam konteks kekiniaan kebebasan akademis dalam pendidikan Islam sudah semestinya menjadi prioritas, terutama karena saat ini sekat-sekat dunia sudah mulai terbuka, dan adalah suatu yang mustahil jika arus perubahan ini dilawan tanpa mempertimbangkan kemungkinankemungkinannya secara mendalam dengan tetap dilandasi oleh prinsip teologis yang kokoh. Intinya kebebasan akademis adalah salah satu kunci untuk mencapai cita-cita besar dari pendidikan Islam.

\section{Hakikat Kebebasan Akademis}

Meskipun disadari, memberikan definisi pada suatu persoalan tidak akan bisa mengungkapkan makna yang sempurna, namun diharapkan dengan pemberian definisi pada kebebasan akademis dalam pembahasan ini akan memberikan pemahaman tentang masalah yang dibicarakan dan tidak terjadi kesimpang siuran dalam penggunaannya. Sebelum berbicara lebih jauh tentang materi ini perlu disadari bahwa pendefinisian secara universal dari kebebasan akademis sulit untuk diungkapkan karena literatur mengenai persoalan ini sangat minim.
Hal ini juga dimaklumi oleh Hasan Asari bahwa definisi kebebasan akademis secara spesifik dalam literature Islam klasik tidak ditemukan, namun para ulama pada masa itu sangat memperhatikan kebebasan belajar.

Dalam lintasan sejarah sosial pendidikan, definisi kebebasan akademis muncul sesuai dengan kepakaran dan tinjauan yang diberikan ahli tersebut. Misalnya kebebasan akademis didefinisikan sebagai tiadanya pengekangan, hukuman, dan intimidasi berkenaan dengan pengkajian, penelitian, pengujian lisan, dan pandangan mereka terhadap pengetahuan betapapun kuno dan subversifnya (Al-Twaijiri, 1988: 21). Maka oleh sebab itu pendefinisian dalam diskusi ini, selain memaparkan pendapat dari para sebahagian tokoh juga akan dikupas dari sudut pandang bahasa Indonesia. Hal ini dilakukan agar pembahasannya nanti lebih terarah dan bisa terkontrol.

Bila dicermati dengan seksama kebebasan akademis terdiri dari dua suku kata yaitu "kebebasan" dan "akademis", keduanya memiliki makna tersendiri. Jika merujuk kepada Kamus Besar Bahasa Indonesia (KBBI) maka kata pertama kebebasan merupakan sebuah kata yang telah dimasuki oleh imbuhan "ke" dan "an", yang kata dasarnya adalah "bebas". Bebas diartikan sebagai pelepas sama sekali (tidak terhalang, terganggu) sehingga boleh bergerak, berbicara, dan berbuat (KBBI: 2008: 152). Kemudian ketika kata dasar ini dimasuki oleh awalan "ke" dan akhiran "an" maka maknanya akan mengalami perubahan yang cukup mendasar seperti terlihat dalam Tesaurus Bahasa Indonesia (2008: 52) diartikan lebih terperinci dan gamblang yaitu independensi, keleluasaan, kelepasan, kelonggaran, kemandirian, kemerdekaan, atau privilese (istemewa) 
(Tesaurus KBBI, 2008: 52). Jadi bila disimpulkan dari sudut pandang ini kebebasan berarti adanya posisi aman bagi setiap orang untuk melakukan aktivitas kehidupan tanpa dibebani oleh rasa khawatir oleh tekanan dari pihakpihak tertentu.

Kemudian makna kebebasan dalam arti yang lebih mendasar dapat juga dilihat dari gagasan Naquib AlAttas yang mengatakan bahwa kebebasan itu adalah merujuk kepada keperibadian diri manusia itu sendiri. Artinya istilah bebas itu merupakan aktivitas yang dilakukan secara sadar yang disertai dengan rasa tunduk dan patuh kepada ruhani dengan cara mematuhi undang-undang serta hukum akhlaqiah yang telah ditetapkan oleh agama dan bukan sebaliknya seperti yang dilakukan oleh orang Barat (AlAttas, 2001: 82). Jadi kebebasan yang dimaksudkan dalam konteks ini lebih mengarah kepada adanya rasa merdeka oleh mahkluk tanpa merasa terbebani, namun kebebasan ini esensinya tidak bisa lepas dari nilai-nilai normatif yang sudah digariskan oleh Allah SWT. Dalam setiap aktivitas ukurannya bukan berdasarkan atas kemauan manusia semata secara membabi buta, tapi ada batas-batas yang tidak boleh diabaikan, itulah ajaran agama. Konsep demikian kiranya berlaku dalam dunia akademisi terutama dewasa ini bahwa seorang ilmuwan dalam aktivitasnya hendaknya selalu memperhatikan nilai-nilaii luhur ajaran agama. Dengan demikian kebebasan yang dimaksud dalam wacana ini adalah sesuatu yang tidak terikat oleh hal-hal yang memberikan konsekuensi untuk mandek maupun monoton dan juga kerangka kebebasan itu memiliki subtansi Ilahiyah yang harus diinternalisasikan dan direalisasikan dalam kehidupan nyata.

Sementara akademis diartikan dengan sesuatu yang berhubungan dengan ilmu pengetahuan, bersifat ilmiah, juga kata akademis ini merujuk kepada perguruan tinggi atau universitas (KBBI: 2008: 25), hal ini menunjukkan kata akademis merupakan penunjukan terhadap orang-orang yang memiliki kecenderungan baik dalam bergelut bersama ilmu pengetahuan dan mereka berkecimpung di dalamnya sesuai dengan kapasitas dan kredibilitasnya masing-masing. Oleh sebab itu dari pendefinisian kebebasan akdemis dapat dipahami bahwa para ilmuwan dengan segala keahliannya membutuhkan suasana yang kondusif tanpa ada intervensi dari pihak-pihak tertentu sehingga akan memungkinkan para ilmuwan dapat mencari, menggali, berinovasi dan mengembangkan berbagai pengetahuan untuk menemukan rahasia-rahasia ilmu Tuhan, karena pada hakikatnya ilmu itu tidak lepas dari Sumber Ilmu itu sendiri yaitu Allah SWT. Hal inilah yang dimaksudkan oleh Osman Bakar (1995: 11) bahwa semangat ilmiah dalam Islam tidaklah bertentangan dengan kesadaran religius (agama), karena ia merupakan bagian yang terpadu dengan Keesaan Tuhan. Semangat demikian tentu lahir dari kesadaran tauhid dan mengalir secara historis dari pengetahuan agama sampai kepada ilmu-ilmu alam, sosial dan lainnya yang melibat tokoh-tokoh besar dalam sejarah Islam.

Jika ditinjau dari sudut lain keberhasilan pengembangan ilmu pengetahuan, kebebasan akademis bukanlah semata-mata syarat mutlak, namun banyak hal yang menjadi syarat penentu untuk mewujudkan cita-cita tersebut. Boleh jadi keberhasilan itu karena ada niat dan motivasi tinggi dari penggunaan fakultas kejiwaan manusia secara optimal, atau bisa jadi adanya sumber-sumber yang orsinil sebagai 
bahan baku untuk dibaca, dianalisis dan direnungkan atau bahkan sebuah keberhasilan para tokoh terkemuka bisa jadi ditentukan karena adanya dukungan-dukungan finansial yang memadai. Intinya mengandalkan kebebasan akademis ini tidak akan menghasilkan apa-apa dan bahkan menjadi ilusi yang tidak pernah ada jika tidak didukung oleh dorongan dalam jiwa manusia, materi, sarana dan sebagainya.

Sekalipun banyak faktor yang mempengaruhi keberhasilan pengembangan ilmu pengetahuan, akan tetapi tersedianya kebebasan akademis merupakan kebutuhan asasi untuk menentukan keberhasilan itu. Kemudian dengan adanya kebebasan akademis, itu artinya ada kegiatan belajar-mengajar tanpa tekanan, mengadakan penelitian, eksperimen tanpa hambatan, mempublikasikan dan mendiskusikannya serta memperdebatkan hasil yang diperoleh oleh para ilmuwan tersebut, hasil yang demikian merupakan ekses dari tersedianya iklim yang kondusif sehingga lahirlah prinsip atau kebenaran yang telah teruji dan terbukti. Maka pantaslah disebutkan bahwa kebebasan akademis diibaratkan fondasi paling bawah dari sturuktur pengembangan ilmu pengetahuan (Asari, 2006: 166).

Lebih terperinci dikemukakan bahwa makna kebebasan akademis adalah kebebasan sebagai sarjana (ilmuwan) untuk menggali kebenaran dan menerbitkannya serta senantiasa terbuka untuk mendiskusikannya secara kritis dengan ilmuwan lain sehingga pada akhirnya dengan keterbukaan itu kebenaran yang digali itu akan menjadi lebih terpercaya dan dapat dipertanggung jawabkan secara ilmiah maupun moral. Kebebasan juga adalah kebebasan dari seorang sarjana dalam bidang keahliannya di dalam memberi pelajaran dan mendidik murid-muridnya mengenai bagaimana kebenaran dalam ilmu pengetahuan itu dapat diperoleh atau diketahui melalui proses-proses yang belaku menurut metode ilmiah atau logika rasional (Asari, 2006: 167).

Dalam perjalanan sejarah Islam banyaklah sudah lahir tokoh-tokoh ilmuwan dari masa ke masa yang telah mampu menelurkan peradaban tinggi dan beberapa abad menjadi prototipe bagi peradaban-peradaban dunia lainnya (pabrik kebudayaan) karena adanya termuan-temuan dengan berbagai corak warna diberbagai cabang ilmu pengetahuan. Bukan maksud untuk mengungkit-ungkit masa lalu untuk membangkitkan anganangan yang indah, namun hal ini adalah sebuah fakta sejarah yang harus diteladani dan digalakkan atau juga untuk antisipasi di masa-masa yang akan datang, karena peran yang dimainkan oleh para ilmuwan muslim di abad pertengahan bukanlah dengan modal sin salabin, akan tetapi jika ditilik secara mendalam ternyata prestasi mereka lahir dari sikap konsistensi terhadap prinsip illmu yang mereka miliki.

Disatu sisi tersedianya kebebasan akademis menjadi penunjang akan keberhasilan itu, tapi disisi lain bahkan tidak jarang terjadi berupa benturan terhadap elemen tertentu (misalkan otoritas politik) yang berujung dengan pembunuhan karakter para ilmuwan, bahkan peristiwa tragis atau menyedihkan telah menghiasi lembaran sejarah Islam masa klasik dan bahkan tidak menutup kemungkinan peristiwa yang sama juga terjadi di masa kini. Hal ini bisa dibuktikan dengan membaca dan menganalisis perjalanan intelektual pada periode tertentu dari masa hidup mereka masing-masing. Deretan nama itu pasti sangat panjang jika dituliskan, 
namun itu bukanlah wilayah kajian dalam pembahasan ini secara tuntas, hanya saja untuk memberikan contoh dan ilustrasi dalam pembahasan ini, dibagian berikutnya akan dikupas sederetan nama-nama yang terpopuler di antara mereka itu.

\section{Kebebasan Akademis Dalam Ajaran Islam}

Tercatat dalam sejarah bahwa ilmuwan-ilmuwan masa lalu dengan segala kapasitas mereka telah mampu mengubah wajah dunia dengan waktu yang relatif singkat. Apa yang mereka lakukan dalam khazanah pengembangan ilmu pengetahuan adalah merupakan sumbangan yang besar dan berarti dalam kehidupan masa kini. Peran yang mereka mainkan itu adalah wujud dari kepandaian dan kepiawaian mereka mengoperasionalkan dan menginternalisasikan ajaran Islam dalam kehidupan nyata dengan bantuan perangkat-perangkat nafs seperti aqal, qalb dan pancaindra.

Pada prinsipnya kata kunci dalam Alqur'an maupun Sunnah tentang kebebasan akademis tampaknya sangat sulit dicari. Bahkan tidak bisa dinafikan bahwa dalam sumber ajaran Islam ini tidaklah ditemukan kata kunci secara eksplisit tentang kebebasan akademis, hal ini juga diakui oleh Hasan Asari dalam sebuah tulisannya bahwa dalam tradisi ilmiah klasik sekalipun konsep kebebasan akademis tidaklah ditemukan, tapi paling tidak secara implisit kiranya dapat dipahami bahwa manusia pada hakikatnya adalah makhluk yang memiliki potensi untuk berbuat baik dan sebaliknya. Sejalan dengan itu Mulyadi menyebutkan bahwa manusia mempunyai kebebasan memilih atau kehendak bebas (Mulyadi, 2005: xxi), ini artinya kebebasan yang dimiliki manusia adalah anugerah yang harus berjalan sebagaimana mestinya. Oleh karena itu untuk memberikan pemahaman terhadap diskursus kebebasan akademis ini beberapa ayat dan sunnah Nabi Muhammad SAW akan diketengahkan (kebebasan akademis perspektif sunnah Nabi dibahas dalam bentuk ilustrasi setelah topik ini).

Dalam tataran normatif ajaran Islam, kebebasan akademis dalam batas-batas tertentu erat kaitannya dengan kebebasan berpikir dan berpendapat atau kebebasan meneliti dan mempublikasikannya. Meletakkan kedua aktivitas ini pada tempatnya adalah sebuah keniscayaan. Jika ditinjau dari perspektif Islam aktivitas berpikir manusia adalah suatu anugerah besar yang tidak pernah dimiliki oleh makhluk lain. Dalam berbagai tempat di dalam Alqur'an, penggunaan akal pikiran benar-benar mendapat perhatian khusus, karena akal itu sendiri adalah salah satu sarana yang cukup mendukung untuk mengantarkan manusia mencapai cita-citanya yaitu menjadi insan paripurna. Sehingga tidak dibenarkan bila penggunaan akal terdistorsi dari esensinya dan aktivitasnya dibatasi oleh kekuatankekuatan asing atas kepentingan pribadi atau juga mendikte akal dengan doktrin-doktrin absurd berdasarkan hawa nafsu yang akan mengakibatkan kemandekan.

Dala Alqur'an kata akal muncul sebanyak 49 kali yang tersebar dalam 30 surah dan 49 ayat. Kata-kata tersebut digunakan dalam berbagai objek, klasifikasi, dan topic pembicaraan. Adapun kata akal yang dibicarakan dalam Alqur'an tersebut selalu digunakan dalam bentuk kata kerja (fi'il) dan tidak pernah disebutkan dalam kata benda (isim). Hal ini menunjukkan bahwa akal bukanlah suatu subtansi (jauhar) yang bereksistensi, melainkan aktivitas dari 
suatu subtansi atau dengan kata lain akal itu adalah proses (Baharuddin, 2004: 118-119). Dari sini dapat dipahami bahwa sebenarnya akal memiliki posisi strategis bagi diri manusia dalam mengaktualisasikan eksistensi dirinya. Akal tidak boleh dinafikan, dikucilkan apalagi membunuh karakternya. Kecenderungan akal untuk bekerja dan berproses merupakan naluri alamiah yang harus mendapat support penuh supaya hasil dari proses yang dilalui tidak akan terjebak karena akal sendiri memiliki kelemahan-kelemahan.

Kemudian bila dirinci penggunaan kata akal dalam Alqur'an ini maka akan ditemui beberapa tekanan sesuai dengan konteks pembicaraannya. Dari 49 ayat yang disebutkan maka terdapat 14 ayat digunakan untuk memikirkan dalil dan dasar keimanan, 12 ayat digunakan untuk memikirkan dan memahami alam semesta, 8 ayat lainnya dihubungkan dengan pemahaman terhadap peringatan dan wahyu Allah SWT, dalam 7 ayat dihubungkan dengan pemahaman terhadap proses sejarah keberadaan umat manusia di dunia, 6 ayat dibuhungkan dengan pemahaman terhadap kekuasaan Allah, 1 ayat dihubungkan dengan pemahaman terhadap hukum-hukum yang berkaitan dengan moral, dan 1 ayat lagi dihubungkan dengan pemahaman terhadap makna ibadah (Baharuddin, 2004: 119-122). Dengan begitu semakin jelaslah bahwa akal dalam ajaran Islam benar-benar sangat diperhatikan, akal bagi manusia terlibat aktif dalam membicarakan persoalan-persoalan mulai dari objek-objek yang riil maupun abstrak, yang bersifat empiris sensual sampai kepada empiris transendental. Alhasil wujud potensial dari penggunaan akal secara maksimal akan mampu mengantarkan manusia kepada posisi yang lebih menguntungkan dalam menjalani kehidupannya.

Oleh sebab itu ketika berbicara tentang kebebasan atau kemerdekaan sebagaimana yang didefinisikan di atas justru pertama sekali harus menampatkan akal pada tempat yang sebenarnya yaitu berpikir secara mandiri. Kemandirian berpikir para ilmuwan muslim zaman dahulu benarbenar memberikan kontribusi besar bagi kehidupan umat manusia, kobaran api Islam telah terbukti bisa menstimulus umat manusia dalam waktu yang relatif singkat sehingga bisa menemukan sisi terdalam dari alam (empiris sensual dan transendental) dan sampai kepada pengetahuan yang sangat berharga. Allah SWT berfirman:

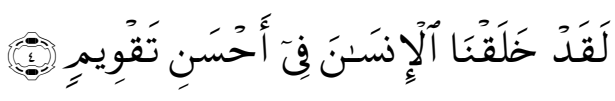

Artinya: "Sesungguhnya kami Telah menciptakan manusia dalam bentuk yang sebaik-baiknya ."( QS. al-Tin, 95: 4).

Hamka dalam tafsir al-Azhar menjelaskan bahwa di antara makhluk Allah SWT di atas permukaan bumi ini, manusialah yang diciptakan oleh Allah dalam sebaik-baik bentuk, bentuk lahir dan bentuk batin. Bentuk tubuh dan bentuk nyawa. Bentuk tubuhnya melebihi keindahan bentuk tubuh hewan yang lain. tentang ukuran dirinya, tentang manis air mukanya, sehingga dinamai basyar, artinya wajah yang mengandung gembira, sangat berbeda dengan binatang yang lain. Dan manusia diberi pula akal. Maka dengan perseimbangan sebaik-baik tubuh dan pedoman pada akalnya itu dapatlah dia hidup di permukaan bumi ini menjadi pengatur. Kemudian Tuhan pun mengutus pula Rasul-rasul membawakan petunjuk bagaimana caranya menjalani hidup ini supaya selamat. Sehingga atas keterangan Hamka ini terlihat manusia seyogianya 
menggunakan akalnya dengan tetap mengacu kepada petunjuk Allah SWT dan Rasul-Nya agar tetap selamat.

Disebabkan manusia adalah makhluk dengan bentuk yang sebaikbaiknya maka tidak dibenarkan menghilangkan satu nyawapun tanpa alasan yang benar. Allah SWT berfirman:

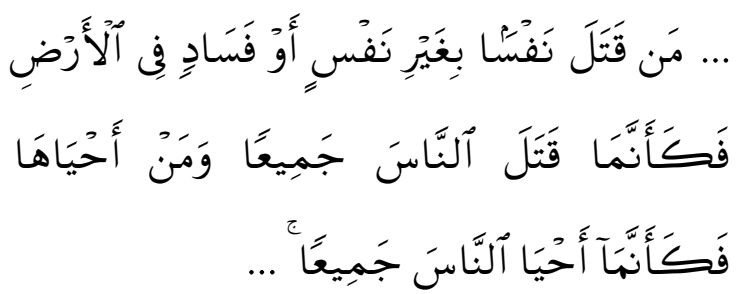

Artinya:“...Barangsiapa yang membunuh seorang manusia, bukan Karena orang itu (membunuh) orang lain, atau bukan Karena membuat kerusakan dimuka bumi, Maka seakan-akan dia Telah membunuh manusia seluruhnya. Dan barangsiapa yang memelihara kehidupan seorang manusia, Maka seolah-olah dia Telah memelihara kehidupan manusia semuanya...." (QS. alMaidah, 5: 32).

Hak Azasi Manusia (human rights) dalam Islam sangat dijunjung tinggi karena manusia adalah makhluk yang diciptakan dengan bentuk yang sebaikbaiknya. Manusia tidak dibenarkan untuk memperlakukan manusia lain dengan hal-hal yang tidak manusiawi, kecuali dengan alasan yang benar menurut petunjuk agama (syari'at). Sehingga dengan tegas Allah SWT memperingatkan dalam surah AlMaidah ayat 32 tersebut bahwa menghilangkan nyawa tanpa alasan yang benar sama halnya dengan membunuh seluruh manusia, dan bagi yang memelihara seorang manusia sama halnya dengan memelihara kehidupan umat manusia. Dengan begitu untuk tidak terjebak ke dalam hal-hal yang merugikan diri maka sangat dibutuhkan jasa akal yaitu untuk belajar sebaik-baiknya supaya dapat mendeteksi dimana yang hak dan yang bathil. Allah SWT berfirman:

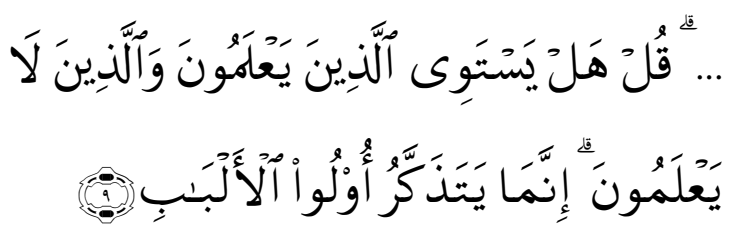

Artinya: "Katakanlah: Adakah sama orang-orang yang mengetahui dengan orang-orang yang tidak mengetahui? Sesungguhnya orang yang berakallah yang dapat menerima pelajaran." (QS. Az-Zumar, 31: 9).

Melalui ayat ini Allah SWT benarbenar mengingatkan manusia bahwa "orang yang mengetahui dengan orang yang tidak mengetahui tidak sama". Mereka berbeda tidak lebih dari hanya disebabkan pengoptimalan potensi kemanusiaan yang ada (qalb atau $a q l$ ). Sekali lagi penggunaan potensi, sebab kalau bentuk materil potensi itu hakikatnya sama yaitu satu sama lain pada umumnya saling memiliki. Itulah sebabnya dalam ayat ini ditekankan bahwa hanya orang yang berakallah yang dapat menerima pelajaran.

Akan tetapi perlu dicatat usahausaha manusia untuk menuju pribadi yang lebih baik dari dirinya yang semula hanya berlaku terhadap diri secara personal, artinya setiap orang pada dasarnya punya hak penuh untuk mengembangkan diri sebagaimana mestinya, tapi dari perspektif lain diri manusia tidaklah hidup secara manunggal namun setiap diri hidup ditengah masyarakat yang memiliki struktural sosial dan keadaan millliu yang berjalan secara dinamis seiring dengan kedinamisan manusia itu sendiri, ini tentu akan memberi warna tersendiri dalam aktivitas akademis seseorang, kapan dan dimana saja hal itu akan berlaku. Jadi fenomena kehidupan komunal manusia ini 
eksesnya sangat besar dan dapat mempengaruhi potensi dasar manusia, pengaruh tersebut dalam wacana aktivitas akademis bisa positif dan bisa negatif. Hal ini sangat ditentukan oleh sejauh mana seseorang mampu memberdayakan akal dan juga mampu menempatkan diri dalam catur kehidupan.

\section{Kebebasan Akdemis Dalam Catatan Sejarah Islam \\ Ilustrasi Kebebasan Akademis dalam lintasan Sejarah}

Masa Nabi Muhammad SAW dan Khulafa al-Rasyidin

Untuk lebih jelasnya kajian kebebasan akademis ini, ilustrasi pertama diawali dengan kehidupan pembawa ajaran Islam itu sendiri. Islam adalah agama Allah yang diproklamirkan oleh manusia pilihanNya yaitu Muhammad bin Abdullah. K. Ali (2003: 35) menyebutkan dalam bukunya A Study of Islamic History bahwa Nabi Muhammad adalah sebagai manusia yang cukup berhasil berintekrasi dengan manusia. Dan Nabi Muhammad ini lahir pada hari Senin, 12 Rabiul Awwal 571 M dari pasangan suami isteri Abdullah dan Aminah. Muhammad dilahirkan dari kalangan suku Quraisy, sebuah suku terhormat dari keturunan Ismailiyah.

Sosok Muhammad SAW semasa hidupnya dalam sejarah menjadi urgen untuk dipelajari dan diteladani. Terkait dengan kebebasan akademis beliau merupakan makhluk yang memiliki sikap terbuka dan egaliter (tidak egois). Posisi Nabi Muhammad sebagai Rasulullah penyampai wahyu kebenaran, beliau juga adalah seorang pemimpin. Namun otoritasnya sebagai pemegang kebijakan tidaklah ia menjadi seorang yang otoriter, malah beliau dalam setiap interaksinya dengan orang disekitarnya selalu dilandasi oleh sikap menghargai dan memberi ruang yang cukup luas untuk berpendapat dan berbeda pendapat. Beliau juga tercatat sebagai pemimpin yang bersedia mengikuti pendapat terbaik (selama tidak memberikan konsekuensi negatif) yang dikemukakan oleh para sahabatnya (Asari, 2006: 170-171).

Contoh yang agak populer ketika Nabi mempraktekkan kebebasan ketika Mu'az bin Jabal hendak dikirim ke Yaman. Sebelum pemberangkatan Mu'az, diriwayatkan pernah terjadi dialog antara Nabi dengan Mu'az sendiri. Percakapan antara Nabi dengan Mu'az ini merupakan gambaran kebebasan yang cukup apresiatif dari seorang Rasul dan pemimpin. Buktinya Rasul memberikan kesempatan kepada Mu'az untuk menggunakan akal fikirannya (ijtihad) jika ada persoalan yang tidak didapati dalam al-Qur'an dan Sunnah. Kebebasan yang diberikan oleh Rasulullah ini melahirkan iktikad dan optimisme bagi Mu'az bin Jabal. Bahkan lebih jauh nabi menyempatkan diri untuk memberikan reward kepada Mu'az sebagai terlihat diakhir riwayat tersebut bahwa Nabi memanjatkan pujian kehadirat Allah SWT yang telah memberikan petunjuk kepada orang yang ia utus.

Contoh lain atas kebebasan yang dipraktekkan oleh Rasul adalah keterbukaan beliau atas ide-ide orangorang disekelilingnya seperti ketika Umar mengusulkan kepada Nabi agar sebagian maqam Nabi Ibrahim as dijadikan sebagai tempat shalat. Dan tidak jarang atas ide Umar sering ada legitimasi hukum dari Allah SWT kepada Nabi SAW. Terkait dengan kasus maqam Nabi Ibrahim ini misalnya ayat tentang ketepatan ijtihad Umar dibenarkan dalam teks ayat dalam QS. Al Baqarah ayat 125: 


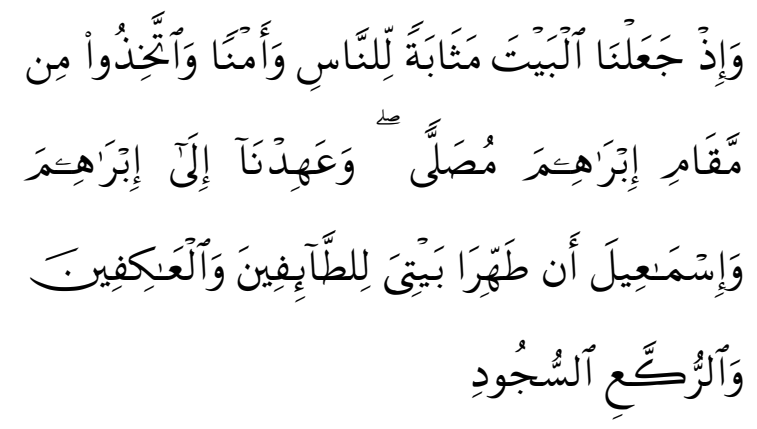

Artinya: Dan (ingatlah), ketika kami menjadikan rumah itu (Baitullah) tempat berkumpul bagi manusia dan tempat yang aman. dan jadikanlah sebahagian maqam Ibrahim tempat shalat dan Telah kami perintahkan kepada Ibrahim dan Ismail: "Bersihkanlah rumah-Ku untuk orangorang yang thawaf, yang i'tikaf, yang ruku' dan yang sujud".

Namun harus dicatat seperti pernah dijelaskan oleh Al Fitri bahwa legitimasi dari wahyu tentang keahlian Umar dalam masalah penetapan hukum sebagaimana kasus di atas sebenarnya bukanlah legitimasi primer Umar. Kesesuaian pendapatnya dengan ketetapan wahyu pada masa risalah sama sekali tidak bisa disimpulkan, bahwa Umar mempunyai nilai otoritatif sebagai sumber hukum. Hal ini disebabkan otoritas penetapan hukum pada masa itu hanya berada pada wahyu dan tindakan Rasulullah SAW. Contoh ini hanya sebuah ilustrasi bagaimana Nabi Muhammad memberi peluang kebebasan kepada para sahabat-sahabatnya. Kiranya pengkorelasian kedua riwayat tersebut terhadap kebebasan akademis dalam wacana ini tidaklah mengada-ngada atau memaksakan tujuan makna teks terhadap kajian kebebasan akademis, tapi hal itu kiranya cukup mendasar karena posisi Nabi SAW sebagai Rasulullah dan Pemimpin memberikan ruang yang cukup efektif dan kondusif untuk mengembangkan kepribadian sahabat-sahabatnya kearah yang positif.
Sementara di masa Khulafa alRasyidin daerah yang dikuasai semakin luas dan termasuk di dalamnya daerahdaerah di luar Semananjung Arabia yang telah mempunyai kebudayaan tinggi dan susunan masyarakat yang bukan sederhana, diperbandingkan dengan masyarakat Arabia ketika itu. Dengan demikian persoalan-persoalan kemasyarakatan yang timbul di periode ini daerah-daerah baru itu lebih sulit penyelesaiannya dari persoalanpersoalan yang timbul di kalangan masyarakat Arab (Harun Nasution, 2009: 5).

Hal itulah yang membuat para sahabat di bawah kontrol khalifah untuk mencari jawaban persoalan itu. Khalifah melakukan ijtihad, namun sebagaimana diketahui para khalifah itu tidaklah memutuskan hukum secara sendiri, tetapi bertanya lebih dahulu kepada sahabat-sahabat lain. Putusan yang diambil dengan suara bulat (konsensus), tentu keputusan ini lebih kuat daripada keputusan satu orang saja.

Namun konsensus hanya berlaku pada masa Abu Bakar saja, mulai dari zaman Usman pengadaan konsensus telah sulit dilakukan sebab para sahabat sudah terpisah-pisah ke tempat daerah yang jauh dari pusat kekuasaan Islam pada waktu itu. Akan tetapi keadaan ini tidaklah menghilangkan kebebasan akademis karena para sahabat diberbagai daerah dengan kewibawaan mereka, mereka melakukan ijtihad, tapi tetap dibawah kontrol khalifah.

\section{Perkembangan Mazhab}

Perkembangan mazhab juga merupakan potret kebebasan akademis yang terjadi secara natural. Berkembangnya mazhab-mazhab dalam dunia Islam membawa kesan semakin meningkatnya perhatian terhadap 
penggunaan akal untuk menggali dan mendalami teks-teks yang terdapat dalam Islam itu sendiri. Adapun meningkatkan perhatian terhadap ajaran Islam dalam perkembangan mazhab ini sebetulnya untuk menjaga dan melestarikan ajaran Islam itu sendiri, disisi lain dalam melestarikan ajaran Islam terdapat sebuah usaha untuk membela dan mempertahankan pendapat antara kelompok. Sehingga tidak jarang praktek mazhab pada masa-masa awal sering menimbulkan ketegangan.

Perlu diketahui untuk menghilangkan paradigma semacam itu, tokoh pembaharu dunia Islam yaitu Muhammad Abduh pernah menjelaskan bahwa tidak ada konflik sesama kaum muslim karena kepercayaan. Perbedaan pendapat yang tajam memang sering mengundang konflik dan bahkan tidak jarang terjadi kontak antara satu golongan dengan golongan lain (misalkan perang Siffin), namun hal itu terjadi merupakan akibat dari persoalan politik dan bukan karena kepercayaan (Abduh, 1987: 20-21).

Sekarang kita kembali pada topik semula, kebebasan akademis dalam bentuk perkembangan mazhab sesungguhnya didorong oleh apresiasi akhirat. Artinya seorang faqih melakukan penelitian terhadap sumber hukum secara independen. Mereka melakukannya karena janji Allah adanya ganjaran akhirat yang menanti. Dalam pembahasan ini bisa kita ambil contoh bagaimana imam Abu Hanifah melakukan pengakajian dan penelitian terhadap hadis atau sunnah Nabi dan para sahabat dalam menetapkan hukum. Beliau keturunan Persia lahir di Kufah pada tahun 700 M. Sebagai bentuk kebebasan akademis bisa kita saksikan bagaimana perkataan beliau yaitu "inilah pendapat saya... dan kalau ada orang lain membawa pendapat yang lebih kuat, maka pendapatnya itula yang lebih benar (Harun Nasution, 2009: 8). Jelas sekali ini ini menunjukkan bahwa dalam dunia keilmuan atau istilah sekarang dunia akademis membutuhkan suasana yang egaliter sehingga akan membentuk semangat para generasi untuk melakukan berbagai penelitian dan pengkajian, karena sama sekali tidak ada pengengakan.

Kemudian kebebasan akademis juga telah melahirkan sosok karismatik yaitu imam Malik. Beliau lahir di Madinah pada tahun 713 M. Dijelaskan beliau tidak turut campur dalam soalsoal politik yang terjadi di zamannya, dan memang sikap demikian merupakan kebiasaan para ilmuwan pada masa itu. Beliau banyak dipengaruhi sunnah Nabi dan sahabat dalam menetapkan hukum, namun kalau ia tidak mendapatkan jawaban dalam al-Qur'an ia pun memakai qiyas dan al-Masalih al-mursalah.

Sebagai bentuk kebebasan akademis yang muncul dari sosok diri Imam malik terlihat ketika Khalifah Harun Al-Rasyid berusaha membuat bukunya Al-Muwatta untuk diberlakukan secara umum, tetapi imam Malik sama sekali tidak menyetujuinya (Harun Nasution, 2009: 10). Maka tampak jelas bahwa beliau menginginkan agar para umat tidak semata-mata terikat akan pendapat beliau secara permanen dengan legalisasi yang dilakukan penguasa. Sebab jika penguasa telah melegalkan pendapatnya yang tertuang dalam bukunya tentu akan menimbulkan stagnan karena merasa telah cukup dengan apa yang sudah ditetapkan. Di saat-saat tertentu kalau ada orang yang tidak sepakat sudah barang tentu penguasa akan lelih mengarah untuk mencekalnya. Selain itu Imam Malik juga sangat egaliter terhadap para 
muridnya dan ia tetap berusaha untuk tidak menjadi pribadi yang otoriter, seperti terlihat dari perlakuannya terhadap murid-muridnya. Salah satu muridnya yang paling brillian adalah Imam As-Syafi'i. Walaupun ia adalah guru Imam As-Syafi'i yang sudah menghafal kitab Al-Muwatta tapi Imam Malik tetap memberi ruang dan tidak mendoktrinisasi secara membabi buta, dan Imam As-Syafi'i sendiri tidaklah menjadikan ajaran gurunya itu sebagai patokan mutlak sehingga ia mampu melahirkan mazhab berbeda dengan gurunya.

Sebuah ilustrasi lain, terdapatlah nama Abu al-Hasan 'Ali ibn Isma'il alAsy'ari yang lahir di Basrah tahun 873 M dan wafat di Baghdad pada tahun 935 $M$ yang dulunya penganut paham Mu'tazilah membentuk teologi baru. Terlepaslah apa faktor-faktor yang menyebabkan ia berpaling dari Mu'tazilah, namun peristiwa ini terindikasi bahwa atas terobosan barunya adalah suatu bentuk kebebasan akademis. Diberitakan bahwa beliau sebelum mempublikasikan gagasannya, ia sempat mengasingkan diri selama lima belas hari untuk memikirkan ajaranajaran Mu'tazilah, kemudian bentuk publikasi atas pemikirannya lewat ceramah dari mimbar masjid (Harun Nasution, 2002: 10).

Oleh sebab itu sikap yang dilakukan oleh Asy'ari ini merupakan bentuk kebebasan akademis, dimana teologi (tanda kutif) sebelumnya bukanlah sesuatu yang permanen untuk menjadi pegangan dan panutan. Kemudian atas penelitian atau ijtihad yang beliau lakukan serta pembublikasiannya yang memanfaatkan tempat umum kiranya dapatlah digolongkan sebagai kebebasan akademis.
Selain daripada itu terdapat nama Ahmad ibn Hambal yang lahir di Bahgdad pada tahun 780 M. Akan tetapi dalam poin ini tidak begitu dibahas secara rinci. Hanya sebagai gambaran terlihat beliau ini memiliki prinsip bahwa hendaknya kebebasan akademis harus menjadi landasan bagi pengembangan ilmu pengetahuan. Untuk lebih jelasnya dalam pembahasan pada poin nomor 2 tentang peristiwa mihna' akan dibahas lebih terperinci.

\section{Perkembagan Filsafat}

Hebatnya arus penerjemahan buku-buku dari Yunani dan Hellenisme adalah wujud dari kebebasan akademis. Ketika warisan Yunani ini dibawa ke dalam peradaban Islam, warisan tersebut kemudian dipelajari dan dikembangkan oleh para eksponennya dengan rasa percaya diri dan semangat kebebasan akademis yang tinggi (Harun Nasution, 2002: 10).

Dalam kajian sejarah Islam dapatlah diketahui bahwa masa Nabi Muhammad SAW aktivitas penjermahan sama sekali belumlah menjadi fokus perhatian, begitu juga pada masa Khulafa' al-Rasyidun. Sementara pada masa Umayyah Usaha penerjemahan karya-karya Yunani, masih bersifat sederhana. Kegiatan penerjemahannya hanya terbatas pada materi-materi yang bersifat praktis, misalnya kedokteran dan kimia. Penerjemahan pada masa ini disponsori oleh Khalifah Khalid ibn Yazid (Hasyim, 2002: 11).

Sementara penerjemahan secara melembaga barulah terdapat pada masa Dinasti Abbasiyah, di bawah pemerintahan Khalifah al-Mansur. Dan puncak kejayaannya pada masa Khalifah al-Ma'mun, ia adalah seorang pecinta ilmu pengetahuan $(215 \mathrm{H} / 830)$. Lembaga penerjemahan ini dikenal 
dengan Baitul Hikmah di bawah pimpinan Hunain ibn Ishak (809-873 M), seorang Nasrani yang ahli bahasa Yunani (Hasyim, 2002: 12). Baitul Hikmah ini sebetulnya berasal dari sebuah perpustakaan yang lebih sederhana, bernama Khizanat alHikmah yang beroperasi semenjak masa khalifah sebelumnya Harun al-Rasyid. Kemudian pada masa al-Ma'mun ditingkatkan kegiatannya dengan memasukkan pengajaran serta proyek penerjemahan karya-karya filsafat dan pengetahuan asing dari berbagai bahasa (Asari, 2007: 198). Dan pada masa ini pulalah hidup al-Kindi (185 H/801 M$252 \mathrm{H} / 866 \mathrm{M})$ seorang yang disebut filsuf pertama Islam.

Deskripsi perkembangan ilmu pengetahuan tersebut merupakan pertanda adanya gembrakan yang sangat luar biasa yang disambut baik oleh kebijakan pemerintah dengan menyediakan fasilitas yang cukup istimewa pada masanya. Walaupun usia peradaban umat muslim saat itu masih relative muda namun justru sudah mampu menunjukkan eksistensinya kepada dunia dengan segudang prestasi sehingga hal demikian dapat mengirim sinyal bahwa kebebasan akademis memang sangat diprioritaskan waktu itu, bahkan kebebasan akademis itu terlihat sangat jelas bagaimana keterbukaan umat muslim tanpa mendiskritkan orang yang diluar pagar (Hunain ibn Ishak) karena ia dianggap mampu membuka jalan untuk mencapai kebenaran sehingga ia pun diangkat menjadi pimpinan pada lembaga resmi Baitul Hikmah.

Dengan iklim yang bersahabat tanpa ada tekanan negative dari pihakpihak tertentu akhirnya peradaban intelektual Islam dapat tumbuh dan berkembang sampai pada puncak yang cukup istimewa yang ditandai dengan keterbukaan dan keberanian para muslim generasi awal tersebut dalam melakukan adopsi dan adaptasi warisan intelektual peradaban kuno yang dijumpainya baik dari Yunai, Persia dan India. Sikap tersebut berada di belakang perkembangan spektakuler di bidang ilmiah dan pendidikan dalam Islam (Asari, 2007: 17). Kebebasan akademis pada periode ini yang dinyatakan telah mampu melahirkan keterbukaan para ilmuwan terhadap penyingkapan tirai kebenaran kiranya bisa dipertegas dengan pernyataan al-Kindi yaitu "Kita tidak perlu malu mengakui kebenaran dan mengambilnya dari sumber manapun datangnya, kalaupun kebenaran tersebut dibawa kepada kita oleh generasi-generasi terdahulu dan bangsa-bangsa asing. Sebab bagi orang yang mencari kebenaran, tak ada nilai yang lebih tinggi dari kebenaran itu sendiri, kebenaran tak pernah merendahkan atau menghindar dari orang yang menerimanya, tapi sebaliknya membuatnya jadi mulia (Stanton, 1994: 102).

\section{Ilustrasi Pergesekan Antara Ilmuan (Kebebasan Akademis) Dengan Otoritas Politik, Birokratis Maupun Agama}

Peristiwa mihna' Al-Ma'mun

Khalifah al-Ma'mun (813-833 M) adalah anak dari Khalifah Harun alRasyid (766-809 M) pada tahun $827 \mathrm{M}$ pernah menjadikan teologi Mu'tazilah sebagai mazhab resmi yang dianut oleh negara. Karena telah menjadi aliran resmi dalam negara, kaum mu'tazilah mulai bersikap menyiarkan ajaranajaran mereka secara paksa, terutama paham mereka tentang al-Qur'an bersifat makhluk, dalam arti diciptakan dan bukan bersifat qadim dalam arti kekal dan tidak diciptakan (Harun Nasution, 2002: 66-67). 
Dengan dijadikannya Mu'tazilah sebagai mazhab resmi negara sesungguhnya memiliki konsekuesni yang cukup signifikan. Ekses dari sikap khalifah ini membuat adanya sebuah pemeriksaan dan pendataan (inkuisisi), serta ada semacam pemburuan sewenang-wenang terhadap seorang (ilmuwan yang tidak sepaham) atau sejumlah warga disakiti, dipersusah, atau ditumpas atau sering disebut dengan istilah persekusi.

Al-Ma'mun dengan kekuasaannya sengaja mengirim surat (instruksi) kepada gubernurnya agar mengadakan mihna' terhadap qadhi diwilayah hukumnya. Oleh sebab itu mihna' ini dianggap sebagai tindakan pelecehan kebebasan akademis yang terjadi pada sejarah peradaban Islam. Peristiwa ini mengakibatkan para ulama kena imbas serius, padahal sikap itu jelas-jelas tidak sesuai atau sejalan dengan hakikat ajaran Islam yang menekan pentingnya kebebasan (Asari, 2007: 175).

Contoh ulama yang kena imbas masa ini adalah Ahmad bin Hambal. Sikap pemerintah dan pengikut aliran mu'tazilah yang bercorak rasional dan liberal itu ditentang oleh beliau. Sama sekali beliau tidak mau tunduk terhadap apa yang mereka inginkan, karena sebagai seorang ilmuwan beliau memiliki prinsip kokoh (Harun Nasution, 2002: 10). Sikap konsisten terhadap prinsip yang dipengangi oleh Ahmad bin Hambal itulah yang membawa beliau masuk penjara. Dan diceritakan meninggalnya Ahmad bin Hambal (12 Rabiul Awal 241 H/ 855 M) karena derita sakit yang dibawanya dari penjara. Sementara disisi lain sikap yang ia memiliki membawa dia menjadi orang yang dihormati dan dikagumi, hal ini bisa dibuktikan dari banyaknya jumlah orang masa itu ikut serta dalam prosesi fardu kifayah beliau.
Politik menyiarkan mu'tazilah secara kekerasan berkurang setelah alMa'mun meninggal pada tahun $833 \mathrm{M}$, dan akhirnya aliran Mu'tazilah sebagai mazhab resmi negara dibatalkan oleh Khalifah al-Mutawakkil pada tahun 856 M.

Pengusiran, Pemenjaraan dan Pembunuhan Terhadap ilmuwan Al-Hallaj

Nama lengkapnya adalah Husayin Ibn Mansur al-Hallaj. Ia populer dikalangan akademisi dengan nama alHallaj. Lahir pada penghujung abad ke dua Hijriyah di desa Baiza Persia. Dia mengenyam pendidikan di kota Thustar di bawah asuhan 'Alim ibn 'Abdullah. Juga di informasikan bahwa al-Hallaj pernah mendapat bimbingan kerohanian dari tokoh-tokoh besar pada masanya, seperti Hazrat Abul Husyin Nuri, Hazrat Junayd Baghdadi, dan Hazrat Umar ibn Uthman. Kematangan intelektual al-Hallaj dan pengalaman spritualnya telah menghantarkan dia pada sebuah kesimpulan atau pandangan yang sangat populer dalam sejarah yaitu ana al-haq (Ibrahim Gazur-i-Ilahi, 1995: xii).

Terkait dengan prinsipnya ana alhaq, Hazrat Zunayd pernah suatu ketika melarangnya agar jagan mengucapkan kata tersebut, karena kata ini dianggap bertentangan dengan syariat. Namun alHallaj tetap dalam pendirian itu dan tidak segan untuk menyerukannya kepada masyarakat masa itu. Sehinnga kalangan ulama syariat bangkit untuk mengkritik dan memberikan perlawanan kepadanya. Gerakan yang mereka lancarkan ini ternyata mendapat respon dan dukungan dari perdana menteri wilayah Baghdad yang bernama Hamid ibn Abbas, kemudian keluarlah fatwa kufur kepada al-Hallaj.

Kasus al-Hallaj kemudian semakin mempiramid setalah kabar itu sampai 
kepada Khalifah Muqtadir Billah. Atas legitimasi para ulama serta gurunya Hazrat Zunayd maka dijatuhkanlah kepadanya hukuman eksekusi mati pada tahun 309 H/921 M (Ibrahim Gazur-i-Ilahi, 1995: xii-xiv).

Vonis mati yang ditimpakan kepada al-Hallaj jelas akibat dari pandangan tasawufnya yang tidak sejalan dengan pandangan tasawuf pada masa itu. Selain itu pandangannya dianggap memberikan dampak negatif yang serius terhadap masyarakat luas (Asari, 2007: 178).

\section{Suhrawardi al-Maqtul}

Adapun identitas dari Suhrawardi al-Maqtul ini di kalangan para pakar berbeda satu sama lain, mulai dari namanya, tanggal lahirnya, bulan lahirnya, tahun lahirnya, bahkan tahun matinya. Tapi ini bukanlah persoalan yang pokok dalam pembahasan ini. Yang paling terpenting pengangkatan tokoh yang satu ini dalam pembahasan makalah ini hanya untuk menggambarkan tentang pergesekan kebebasan akdemis itu sendiri. Hanya saja seperti dalam tulisan Ja'far, kendati terjadi polemik seputar kehidupannya, akan tetapi bisa disimpulkan bahwa Suhrawardi yang dimaksud itu dilahirkan di desa Suhrawardi sebuah desa kecil dekat kota Zanjan (Ja'far, 2011: 66).

Diinformasikan bahwa kota Aleppo sebagai kota propinsi dari Dinasti Ayyubiyah menjadi tampat persinggahan terakhir dari Suhrawardi. Di daerah inilah Suhrawardi berdomisili untuk beraktivitas. Dengan berbagai aktivitas kelimuan yang ia lakukan membuat dirinya menjadi orang yang disegani, bahkan dalam waktu yang relatif singkat ia sudah mampu menempati posisi penasehat dan sekaligus jadi guru dari gubernur
Aleppo yang pada saat itu dipimpin oleh Malik al-Zahir (Ja'far, 2011: 76-77).

Atas keberhasilan yang diraihnya membuat para hakim, wazir dan fuqaha Aleppo tidak senang dengan status Suhrawardi. Apalagi sebelumnya dalam forum-forum diskusi Suhrawardi dianggap tidak sepaham dengan mereka (aliran Suni), dan keyakinan Suhrawardi disebut-sebut sebagai Syi'ah Ismailiyah. Kemudian dia dianggap sesat, penyeleweng agama, perusak agama, bahkan kafir. Ketidak senangan mereka pada akhirnya termanisfestasikan dalam legitimasi eksekusi mati untuk menyingkirkannya dengan meminta tuntutan gubernur untuk memvonisnya, namun gubernur Aleppo menolaknya. Sehingga tembusan tuntutan itu sampailah kepada penguasa Dinasti Ayyubiyah yang dipegang oleh Salah al-Din alAyyubia di Mesir. Kemudian tuntutan ini dikabulkan setelah terlebih dahulu dipertimbangkan. Akan tetapi pertimbangan itu disebut-sebut tidak lebih hanya sebagai pertimbangan politis (Ja'far, 2011: 78).

\section{Ilustrasi Kebebasan Akademis di Indonesia}

Pembahasan yang penulis angkat dalam konteks ke-Indonesian ini sebenarnya tidak begitu relevan sebagaimana terlihat dalam judul besar artikel ini yaitu kebebasan akademis dalam pendidikan Islam klasik. Namun untuk memberikan ilustrasi yang lebih konkrit tentang permasalahan bagaimana kebebasan akademis itu, makanya dinamika para ilmuwan yang lebih dekat dengan kehidupan kita pantas untuk dibicarakan, dan menurut penulis fakta sejarah yang ada juga secara subtansi pembahasan bukanlah sesuatu yang melenceng. 
Di Indonesia misalnya pada abad 17-an catatan sejarah memberikan informasi bahwa ada terjadi kasus pembakaran buku-buku ilmuwan letaknya di daerah Aceh pada masa Kesultanan. Peristiwa ini merupakan pengekangan terhadap seorang intelektual yang bernama Hamzah Fansuri dari seseorang yang notabenenya juga adalah seorang ilmuwan yang bernama Nur al-Din alRaniri (Asari, 2006: 176).

Hamzah Fansuri disebutkan adalah seorang filsuf pertama yang berkebangsaan melayu. Ia adalah syekh tarekat Qodiriyah yang pertama di Indonesia, sebuah tarekat yang didirikan oleh Abdul Qadir Jaelani (w. 1166). Tentang asal usul Fansuri ini para ahli satu sama lain berbeda pendapat menetapkan waktu dan tempat kelahirannya (Ja'far, 2010: 208). Tapi yang jelas sebagaimana terdapat dalam Asari bahwa beliau ini pernah hidup pada abad ke-17 sebagaimana disebutkan di atas.

Sebagai seorang tokoh Fansuri pernah mendirikan lembaga pendidikan Islam sebagai wadah pembelajaran Islam, terutama penyebaran ajaran sufistiknya. Buktinya, ia membuka dayah di kampung Oboh Simpang Kiri, Rudeng di Hulu Sungai Singkel. Sehingga dengan berdirinya lembaga ini terbuktilah Fansuri adalah seorang yang concern terhadap dunia pendidikan Islam (Ja'far, 2010: 213).

Sementara al-Raniri nama lengkapnya adalah Nur al-Din al-Raniri bin Hasanji bin Muhammad Hamid alRaniri, dan dikenal sebagai seorang mujaddid paling penting di nusantara abad ke-17 M. Dia lahir di Ranir, Gujarat, ibunya diketahui adalah seorang melayu, dan ayahnya berasal dari keluarga imigran Hadhrami (Ja'far, 2010: 205).
Pergesekan yang terjadi antara Fansuri dan al-Raniri ketika aliran tasawuf wujudiyah lebih dominan di kalangan masyarakat Aceh masa itu, dimana motor penggeraknya adalah Fansuri. Namun al-Raniri menganggap Fansuri adalah seorang sufi gadungan, bahkan ajaran-ajarannya adalah sesat. Kritik yang dilancarkan oleh al-Raniri akhirnya menjelma menjadi sebuah keputusan yang isinya perintah untuk membakar karya-karya mereka, dan juga perintah untuk memburu atau membunuh orang-orang sesat jika mereka tidak mau bertaubat (Asari, 2006: 176). Dan yang paling ironisnya keberhasilan sikap al-Raniri tersebut ternyata bergerak atas backup-an dari penguasa atau Sultan.

Dari kasus perseteruan antara Fansuri dan al-Raniri dari tinjauan kebebasan akademis sebenarnya tidak harus terjadi, apalagi perseteruan itu melibatkan penguasa atau sultan. Jika sudah penguasa mendikte para ulama atau ilmuwan untuk kepentingan kekuasaannya maka akan terjadi ketimpangan. Boleh saja penguasa turut dalam mensukseskan pencarian kebenaran namun penguasa harus mampu menempatkan dirinya sebagai penguasa dan pencari kebenaran. Peristiwa yang terjadi antara Fansuri dan al-Raniri dengan sokongan sultan ini adalah contoh kecil yang menggambarkan bagaimana iklim akademis tidak harmonis bagi suatu kelompok yang mengakibatkan mereka harus tersingkir dari upaya proses pemanfaatan dan penginternalisasian potensi-potensi kemanusiaannya untuk mencapai kebenaran.

\section{SIMPULAN}

Dari penjelasan-penjelasan di atas, maka disini penulis akan menarik beberapa kesimpulan yaitu bahwa 
kebebasan akademis adalah prasyarat untuk seorang pecinta ilmu atau sering disebut "ilmuwan" untuk dapat mengekspresikan kemampuan akal pikirannya dalam melakukan aktivitas seperti penelitian, pengkajian, pengembangan, mempublikasikannya serta dapat mentransformasikannya kepada generasi-generasi berikutnya dengan tetap memperhatikan nilai-nilai luhur dari ajaran agama Islam itu sendiri.

Di satu sisi kebabasan akademis tidaklah menghambat seorang ilmuwan untuk mencari kebenaran. Atas prinsip kebenaran yang diyakini sah-sah saja untuk dipertahankan, hal inilah yang ditunjukkan oleh Ahmad bin Hambal dan al-Hallaj pada masa mereka. Tidak boleh sekali-kali mengorbankan prinsip keilmuwan hanya karena sesuatu yang pragmatis. Dengan kebebasan akademis dalam arti positif telah terbukti mampu melahirkan para ulama atau ilmuwan muslim terhitung dari tahun 750-1100 $\mathrm{M}$, ini adalah bukti nyata bahwa ajaran Islam telah mampu mendongkrak dan memotivasi penganutnya untuk dapat semaksimal mungkin mendayagunakan potensi kemanusiannya secara mandiri dan aman dari tekanan.

Kemudian bagi setiap pendidik hendaknya mampu menempatkan diri sebagai guru semata tanpa harus menjadi guru berkedok penguasa. Berbagai faktor yang dianggap mempengaruhi kestabilan kepribadian guru hendaknya mampu diminimalisir dalam kaitannya dengan proses pembelajaran. Walaupun kadang ada situasi yang tidak bersahabat ketika berlangsungnya proses pendidikan tapi sebagai guru hal itu harus dapat dimaklumi dan senantiasa berusaha seoptimal mungkin untuk dapat mengatasinya dengan bijaksana.

\section{DAFTAR RUJUKAN}

Abduh, Muhammad. 1987. Ilmu dan Peradaban Menurut Islam dan Kristen, terj. Mahyuddin Syaf dan A. Bakar Usman. Bandung: Diponegoro.

Al-Attas, Syed Muhammad Naquib. 2001. Risalah Untuk Kaum Muslimin, cet. I, Kuala Lumpur, ISTAC.

Al-Fitri. Hakim Pratama Madya pada Pengadilan Agama Tanjungpandan Kelas II, wilayah Pengadilan Tinggi Agama Kepulauan Bangka Belitung.

Al-Twaijiri, Ahmed Othman. 1988. Kebebasan Akademis Konsep Islam dan Barat, terj. F. Rozi Dalimunthe dan Nur A. Fadhil, Medan: Sumber Ilmu IAIN SU.

Arsyad. M. Natsir. 1997. Cendekiawan Muslim dari Khalili sampai Habibie, cet. Ke-2, Jakarta: Raja Grafindo Persada.

Asari, Hasan. 2006. Menguak Sejarah Mencari Ibrah cet. I. Bandung: Citapustaka Media.

Asari. Hasan. 2007. Menyingkap Zaman Keemasan Islam, edisi revisi. Bandung: Citapustaka Media.

Baharuddin. 2004. Paradigma Psikologi Islam, Studi Tentang Elemen Psikologi dari Alqur'an, Penelitian Disertasi, Yokyakarta: Pustaka Pelajar.

Charles Michael Stanton. 1994. Pendidikan Tinggi Dalam Islam, Terj. H. Afandi dan Hasan Asari. Jakarta: Logos Publishing House.

Departemen Pendidikan Nasional. 2008. Kamus Besar Bahasa Indonesia. Jakarta: Pusat Bahasa,.

Departemen Pendidikan Nasional. 2008. Tesaurus Bahasa Indonesia, Jakarta: Pusat Bahasa, 2008.

Gazur-i-Ilahi. Ibrahim. 1995. The Secret of Ana'l-Haqq, terj. Bandahara dan 
Joebaar cet. I. Jakarta: Raja Grafindo Persada.

Ja'far. 2001. Manusia Menurut Suhrawardi al-Maqtul. Banda Aceh: Yayasan PeNA Banda Aceh.

Ja'far. 2010. Warisan Filsafat Nusantara, cet. I, Banda Aceh, Yayasan PeNA Banda Aceh.

K. Ali. 2003. A Study of Islamic History, terj. Sejarah Islam "Tarikh Pramodern". Jakarta: Raja Grafindo Persada.
Nasution, Harun. 2009. Islam Ditinjau Dari Berbagai Aspeknya, Jilid II, Jakarta: UI-Press.

Nasution, Harun. 2002. Teologi Islam, Aliran-Aliran, Sejarah Analisa Perbandingan, cet. I. Jakarta: UIPress.

Nasution. Hasyimsyah. 2002. Filsafat Islam, cet. Ke-3. Jakarta: Radar Jaya Jakarta. 